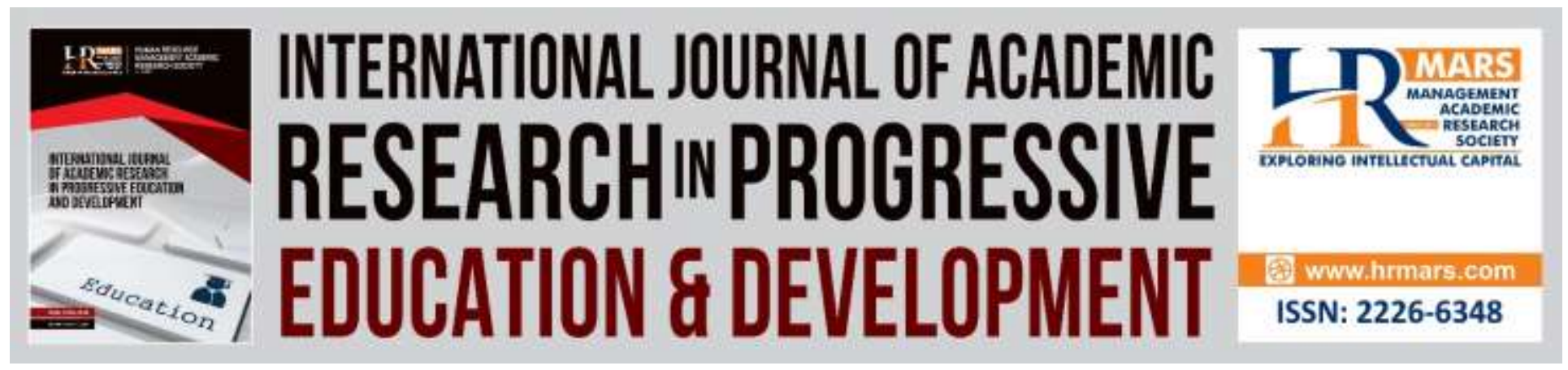

\title{
Synergizing Mathematical Learning for Future Ready Curriculum using Adventure-Based Learning
}

Nor'ain Mohd Tajudin, Mohd Afifi Bahurudin Setambah, Norsida Hassan, Noorazrin Abd Rajak, Mazlini Adnan

To Link this Article: http://dx.doi.org/10.6007/IJARPED/v8-i4/6719 DOI:10.6007/IJARPED/v8-i4/6719

Received: 15 November 2019, Revised: 30 November 2019, Accepted: 11 December 2019

Published Online: 26 December 2019

In-Text Citation: (Tajudin et al, 2019)

To Cite this Article: Tajudin, N. M., Setambah, M. A. B., Hassan, N., Rajak, N. A., \& Adnan, M. (2019). Synergizing Mathematical Learning for Future Ready Curriculum using Adventure-Based Learning. International Journal of Academic Research in Progressive Education and Development, 8(4), 778-794.

Copyright: (C) 2019 The Author(s)

Published by Human Resource Management Academic Research Society (www.hrmars.com)

This article is published under the Creative Commons Attribution (CC BY 4.0) license. Anyone may reproduce, distribute, translate and create derivative works of this article (for both commercial and non-commercial purposes), subject to full attribution to the original publication and authors. The full terms of this license may be seen at: http://creativecommons.org/licences/by/4.0/legalcode

\section{Vol. 8(4) 2019, Pg. 778 - 794}

Full Terms \& Conditions of access and use can be found at http://hrmars.com/index.php/pages/detail/publication-ethics 


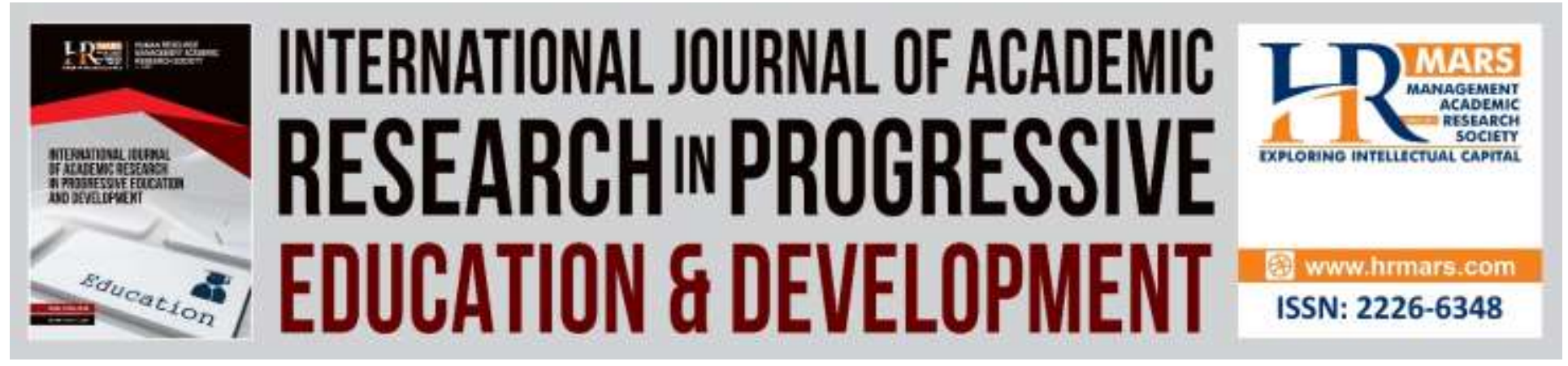

\title{
Synergizing Mathematical Learning for Future Ready Curriculum using Adventure-Based Learning
}

\author{
${ }^{1}$ Nor'ain Mohd Tajudin, ${ }^{2}$ Mohd Afifi Bahurudin Setambah, \\ ${ }^{3}$ Norsida Hassan, ${ }^{4}$ Noorazrin Abd Rajak, ${ }^{5}$ Mazlini Adnan \\ 1, 2, 3, 4, 5 Sultan Idris Education University, Malaysia, ${ }^{5}$ Research and Development Department, \\ IPG Kampus Bahasa Melayu, Malaysia, \\ Email: ${ }^{1}$ norain@fsmt.upsi.edu.my, ${ }^{2}$ mohdafifi@ipgkbm.edu.my, ${ }^{3}$ norsida@fsmt.upsi.edu.my, \\ ${ }^{4}$ noorazrin@fsmt.upsi.edu.my, ${ }^{5}$ mazlini@fst.upsi.edu.my
}

\begin{abstract}
The adventure learning consists of highly structured physical activity with debrief session that helps promote personal and social development. It is an approach with the future ready curriculum framework that highlights three elements; curriculum structure, learning and teaching delivery and assessment that are constructively aligned to prepare graduates in meeting the challenges of the $21^{\text {st }}$ century. Previous researches showed that future adventure learning projects are recommended to focus on higher education, small and diverse which can yield significant knowledge into adventure learning. Thus, this study aims to develop an adventurebased learning module for learning statistical inference course at diploma level. This article will highlight two activities of adventure learning in the developed module. The experiential learning theory, the inquiry-based learning and the concept of outdoor learning point of views will be explained to shed additional light on the way the activities in adventure learning endeavors are formed and enacted. This study contributes valuable opportunities for higher education, where connecting learners with real-life and relevant explorations may be the links missing to make higher education experiential, authentic, and engaging.
\end{abstract}

Keywords: Adventure-Based Learning, Future Ready Curriculum, Statistical Inference, Higher learning

\section{Introduction}

Over the years, the delivery of Higher Education Programs around the world has transformed significantly. Not left behind, the Malaysian Higher Education Programs has promotes students diversifications of roles as curators of knowledge, content produces, connections-makers, the web as the open global curriculum and educators as the resources guide (Hamisah \& Marlia, 2018). The need for Future-Ready-Curriculum (FRC) is critical in uplifting graduates' knowledge, skills and attributes to thrive in the gig economy world. In a FRC, the curriculum, instruction, and 
assessment are tightly aligned, redesigned to engage students in 21st Century, personalized, technology-enabled, and deeper learning. Curricula and instruction are standards-aligned, research-based, and enriched through authentic as well as real-world problem solving. Students and educators have robust and adaptive tools to customize the learning, teaching, and assessment, ensuring that it is student-centred and emphasizing deep understanding of complex issues. Assessments are shifting to be online, embedded, and performance-based. Institutions need to ensure that the education they offer meets the expectations of students and the requirements of employers, both today and for the future.

Till now, issues regarding the quality of teaching in higher education are often discussed to ensure students' success and educators' performance (Aliu \& Aigbavboa, 2019; Brown, Cooper-Thomas, Curtin, Dunham, 2019). Not to be denied, educators as well as researchers have often sought to engage learners in authentic, contextual and experiential learning in an attempt to connect activities in the classroom with learners' lives beyond the classroom walls (Veletsianos \& Kleanthous, 2009; Tan \& Nie, 2015; McRae, Church, Woodside, Drewery, Fannon, \& Pretti, 2019). One promising way to engage learners in FRC, therefore, has been through the development of educational programmes or activities that revolve around expeditions and adventures grounded on the use of technology to reinforce the experience and connect learners, educators, and experts (Buettner \& Mason, 1996; Buettner, 1997). Given the potentially powerful and lasting impact that such programs have exhibited (Hattie, Marsh, Neill, \& Richards, 1997), the interest from the educational community (Schutz, 2008), and the relative confusion that exists in the current literature with regards to how powerful outcomes are achieved in adventure-based education (Hattie et al., 1997; McKenzie, 2000). ABL has only been implemented as a distance education approach in the K-12 environment in the context of large-scale projects focusing on socio-scientific issues of global concern. While these projects demonstrate the possibilities afforded by $A B L$, the opportunities, limits, and viability of $A B L$ in other contexts need to be investigated. This can be done by designing and researching projects that are smaller in size and scope, explore other content areas, and focus on higher education. Thus, this study aims to develop an Adventure-Based Learning Module for learning Statistical Inference course at Diploma level. This article will also highlight two activities of adventure learning in the developed module.

\section{Literature Review}

Concepts of Adventure-Based Learning

Adventure-Based Learning ( $A B L$ ) uses an experiential and discovery learning approach as well as fun approach to trying something new to support the concept that one learns most effectively when they: (i) Enjoyed the learning activities, (ii) Interested in what was learned, (iii) Actively participate in their learning, (iv) Feeling in control of what they learn, (v) Able to reflect the experience afterwards, and (vi) Making connections to other learning and other life situations. In $A B L$, the lecturer or facilitator challenges the group to achieve its goals, but does not explain how to successfully complete the exploration challenge. Students must strive to find solutions individually and together as a team, must communicate and learn from one another in order to succeed. In this teaching method, students are able to identify the internal resources, strengths, 


\section{INTERNATIONAL JOURNAL OF ACADEMIC RESEARCH IN PROGRESSIVE EDUCATION AND}

DEVELOPMENT

Vol. 8, No. 4, 2019, E-ISSN: 2226-6348 @ 2019 HRMARS

and positive attributes within themselves and in their team. Students can reflect and respond to subsequent experiences or "adventures" that allow them to learn more about both the group's personal behaviors and contributions, and relate them to their daily lives and routines to bring about a more positive change. Positive changes often occur when students, individually and as a group, resolve problems or face situations of risk.

There are several examples of $A B L$ programs that have been implemented, namely GoNorth 2006-2009, Arctic Transect 2004, Jason Project, The World of Wonders, Blue Zones, Expedschools and eField Trips (Veletsianos \& Kleanthous, 2009). However, the approaches and strategies used in each of the above ABL vary. For example Expedschools uses a project-based approach, eField Trips based on a virtual project, conducting outdoor activities only and combining virtual projects and outdoor activities.

\section{Adventure-Based Learning Principles}

Doering (2007) introduces several key principles in the ABL Model such as illustrated in Figure 1 which include:

i. Curriculum-based and inquiry-based (problem-based learning),

ii. Opportunities for collaboration and interaction between students, lecturers and experts,

iii. Using the internet as a medium of learning,

iv. Media and text can be delivered on time,

v. Syncronized in educational opportunities,

vi. Guidelines for implementing online curriculum pedagogy, and

vii. Adventure-based education

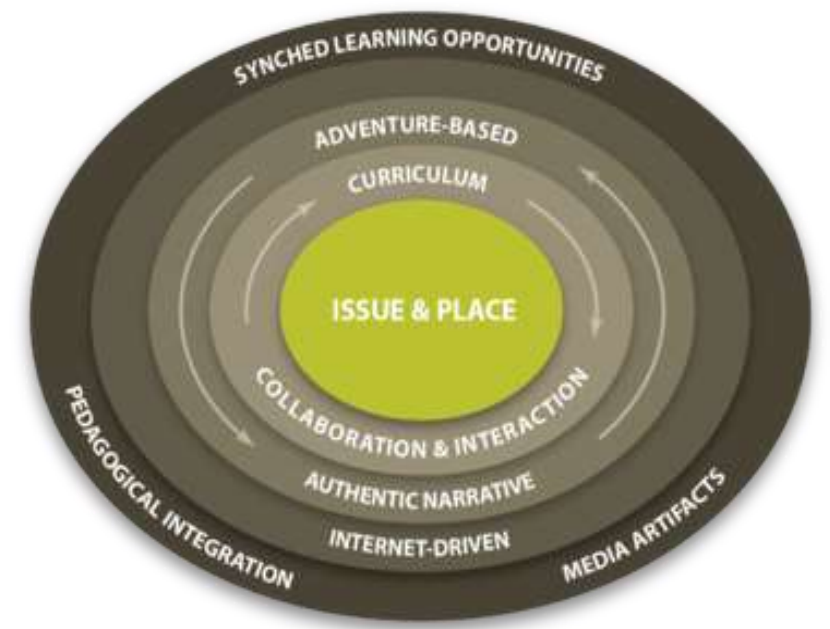

Figure 1: Adventure- Based Learning Model (Doering, 2006) 
The implementation of $A B L$ should take into account all of the above principles. The research and inquiry-based curriculum is the first principle of $A B L$. This principle requires us to highlight problem-solving learning concepts involving active student engagement. The second principle is the opportunity for collaboration between students, lecturers and experts. This principle means that during the learning process using the $A B L$ method, interaction between students, lecturers and scholars is required. The third and fourth principle is that the use of the internet as a medium of learning and media and text can be delivered in a timely manner. This principle emphasizes the concept of information sharing through mediums such as smartphones or laptops. Thus, the use of the internet is crucial as a medium of media and text sharing. The next principle is that consistency in educational opportunities means that students can share and ask about any learning problem through a medium or group site that has been developed such as Whatsapp group or facebook group. Sixth is to have a pedagogical implementation guide. The guide is designed so that lecturers using this method can develop the medium or group page mentioned above. The last principle is adventure-based learning or exploration. Therefore, adventure activities are required during the teaching and learning sessions of this method.

$A B L$ that have been implemented in many current studies are of large size, scope, duration and funding (Veletsianos \& Kleanthous, 2009). This method is also practiced only in the social sciences in certain areas. This method can actually be used in education, in any location or in any other content area using ABL on a smaller scale (Veletsianos \& Kleanthous, 2009). This means that the $A B L$ can be practiced by lecturers in the college or university as well as by educators in their classes.

Theories and Concept Related to ABL

The following discusses the three learning theories that are fundamental to $A B L$ namely the experience-based learning, the inquiry-based learning and the outdoor-based learning. The relation of theory and $A B L$ is explained in each of the following subtopics.

\section{(a) Experience-Based Learning}

Humans are learning since their birth in this world. It doesn't matter whether it's formal or informal. The experience-based learning takes place everywhere. For example, a child told her mother to buy sugar at a store near the house. This situation indicates that the child will conduct a learning session based on the experience he or she has with his or her mother, father, brother, sister or anyone who has brought him to the store. This process, as described by Kolb's (1984) is the experience-based learning model. Kolb's (1984) learning model is a well-known learning model. The learning model is illustrated in Figure 2. 


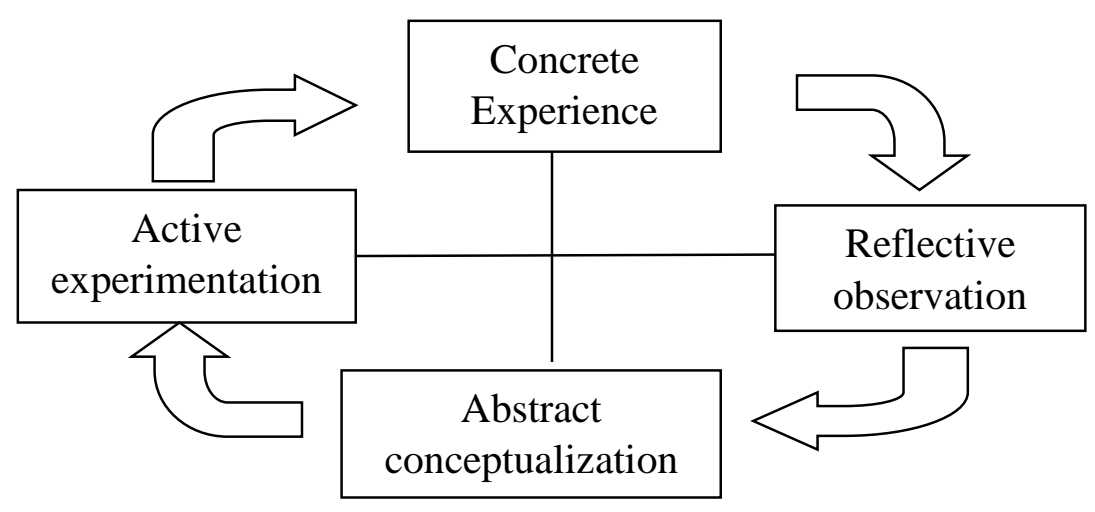

Figure 2: Experience Based Learning Models

Kolb's (1984) learning model is the result of John Dewey's adaptation of ideas. Students learn based on four cycles of concrete experience, reflective observation, abstract conceptualization and active experimentation. Students need to engage fully with open and unbiased thoughts during concrete experiences. Next, reflect on and interpret the experience according to one's own understanding (reflective observation). The next cycle is integrating observation and logical theory to form the abstract concepts. Finally, they make assumptions and conclusions based on new theories in the active experimental phase (Kolb \& Fry, 1975). Experience-based learning is often practiced by students, especially involving practical training. This approach is applied to students and it is said to be most effective if the student is himself or herself involved in the teaching and learning process. Beard and Wilson (2013) define experience-based learning as the knowledge gained from consciously or unconsciously transferring information or knowledge through observation and experience.

Based on Kolb's (1984) cycle model and the characteristics of experience-based learning, the ABL method exhibits the characteristics of this approach. In other words, the ABL method is a subset of experience-based learning. This is seen when an adventure activity combined with a particular task provides experience, and creates a positive reflection on the skills, attitudes and ways of students' thinking. However, the differences between the ABL method and this experience-based learning are reflected in the activities implemented.

\section{(b) Inquiry-based learning}

Inquiry-based learning means learning that involves investigating a problem, finding solutions, analyzing problems and making decisions based on the information obtained. According to Thangavelo, Azman and Rodziah (2001), learning that has features such as identifying, exploring and investigating information on a problem or phenomenon is a definition of inquiry-based learning. This approach is one of the student-centred approaches (Noraini, 2005) in which students are given autonomy in each activity. Panaoura (2017) argues that inquiry-based approaches provide opportunities for students to actively engage in acquiring mathematical concepts. Consistently, Chapman's (2011) also explain the learning that occurs when students 
engage in research and problem-solving activities with the help of lecturers is inquiry-based learning.

There are five steps involved in implementing this approach. It starts with a problem-solving step. Therefore, the construction of tasks that will be used during the teaching and learning sessions must contain problems that need to be resolved. Next, the lecturers will need to help students in making predictions about possible solutions and guide students in collecting data. Students then analyze the data collected to draw conclusions or conclusions about the given problem. This process is summarized through Figure 3.

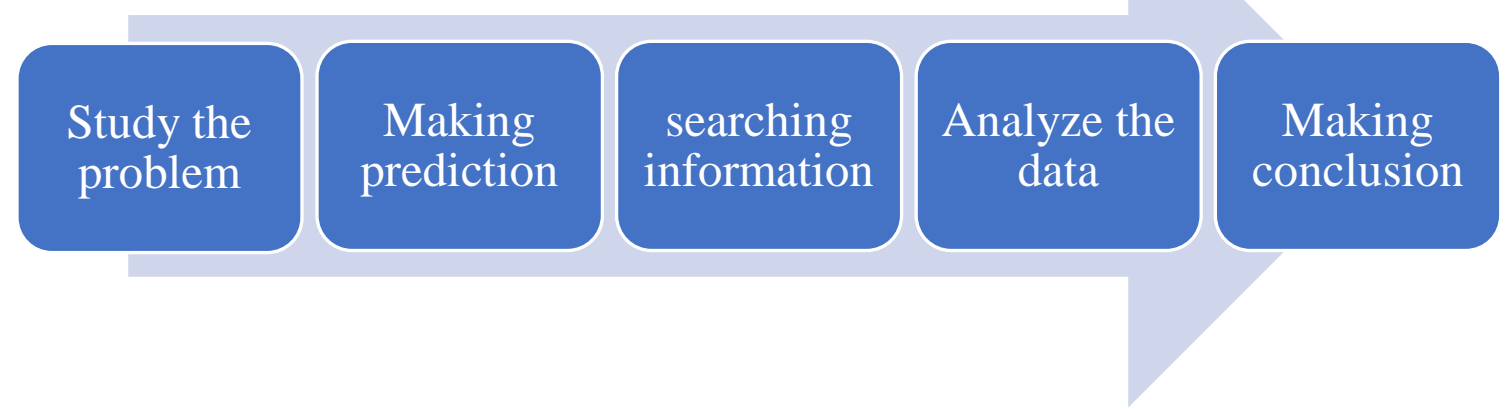

Figure 3: The Inquiry-Based Approach Process

The $A B L$ method in mathematical contexts requires that the lecturer form an inquiry task involving adventure activities. This is important so that the ABL method practiced can guarantee the achievement of predefined learning outcomes. A problem-solving task needs to be developed and built on an inquiry-based approach that involves studying the problems, making predictions, searching information, analysing the data and making conclusion. In addition, the activities created should have an element of adventure. Therefore, the ABL method developed is also a subset of inquiry-based learning.

\section{(c) Outdoor Learning}

Outdoor learning is defined as a learning activity that engages in external activities that enhance the personality and social well-being of the natural environment (Marchant et al., 2019). It can be carried out anywhere in zoos, forests, factories and so on (Ford, 1986; Fox \& Avramidis, 2003). Outdoor learning is defined as learning outside of the classroom with elements of adventure (Sibthorp \& Jostad, 2014). Therefore, classroom learning in this context is a learning session that is related to adventure activities and is carried out in a natural environment and not in the classroom.

According to Bowdridge (2010), outdoor education is very practical for the implementation of the experiential learning philosophy. There are various outdoor learning activities that are synonymous with adventure activities. These include walking, biking, camping, water activities, mountain climbing, rope activities (abseiling, flying fox), rock climbing and so on (Dickson, Gray, 
\& Mann, 2008). These activities are also used during the National Service Training Program (PLKN) in the FIT4LIFE module. This module is developed to shape and improve individual performance and quality. As such, $A B L$ can be practiced during classroom learning which used outdoor learning perspectives when an adventure element is incorporated into that approach.

\section{Objectives of the Study}

This study aims to develop an Adventure-Based Learning Module for learning Statistical Inference course at Diploma level. This article will also highlight two activities of adventure learning in the developed module.

The research questions for this study are:

1) Does the developed $A B L$ module for the Statistical Inference course have satisfactory validity?

2) Does the developed $A B L$ module for the Statistical Inference course have satisfactory reliability?

3) What are the two activities of adventure learning in the developed module?

The justification of choosing the Diploma Level Statistics course in this study is as follows:

1) Statistics is a branch of science in mathematics. The use of this field in everyday life is widespread and the importance of learning it should not be denied (Chew \& Dillon, 2014; Johnson \& Kuby, 2012; Gal \& Ograjensek, 2017; Yeoh, Afifi, Ket \& Narmal, 2015).

2) This Basic Statistics course is mandatory for all students in the Diploma in Science (Mathematics) Program, though it is significant in all fields of education for all levels of schooling from pre-school to higher education (Chew \& Dillon, 2014; Kalaian \& Kasim, 2014; KPM, 2015). Therefore, the choice of Statistics course at the Diploma level is appropriate as it is the most basic course in the university and the usefulness of the $A B L$ method in the early stages can give an indication of its usefulness or usefulness at the next level. If this method produces positive results, then its application to all courses can be expanded.

\section{Methodology}

This study aims to develop the ABL Module for Inferential Statistics Course for Diploma Mathematics Programme students. For this purpose, the development and design research design is used (Creswell, 2018). The design is suitable due to its pragmatism in testing the theory and validating the practicality. Besides, it is described as a way to establish new procedures, techniques and tools based on specific needs analysis (Richey \& Klein, 2007). In this case, a new teaching module was developed. To develop the module, this study adopts a model of module development by Afifi (2017) based on the ADDIE Model (Piskurich, 2016) and Kemp Morrison and Ross (2012). There are five main phases in developing modules, namely the analysis, the design, the development, the implementation, and the evaluation phases. The analysis phase is the basis of all phases. The following will be determined before the module is developed: the process of identifying the module objectives, course content, assignments and teaching contexts. Document analysis was also carried out on the specification of the Course Framework and Course Instructional Plan for Statistical Inference course. 
The second phase is the design phase of the ABL Module development. Kemp, Morrison, and Ross (1998) stated that the basis for the process of designing a teaching module involving four main elements;- students, objectives, methods and assessments. Therefore, in this phase, the following elements are determined; determining the learning outcomes, approaches, strategies, tasks, activities and appropriate teaching resources.

The next phase is to develop the $A B L$ module. In this phase, lesson plans, course content, assignments, training and teaching aids are developed. The completed $A B L$ module is validated by three mathematics education experts. The next phase is the implementation phase where the teaching and learning activities will be implemented and involves two processes. The process involves mentoring for teachers and implementing teaching and learning in a real context. Selected teachers will be given teaching and learning implementation guided by the ABL Module. Finally, the evaluation phase was implemented where the teaching and learning activities using the $A B L$ module are carried out to investigate the feasibility and the reliability of the module being developed.

\section{Sample of the Study}

There are two types of samples in this study; the sample to validate the modules and the sample to determine the reliability of the $A B L$ module. Three mathematics education experts are selected using the purposive sampling technique. A sample of 30 randomly selected mathematics teacher trainer participated in the evaluation phase.

\section{Instruments}

The instruments used in this study are the Content Validity Form (CVF) and the Module Reliability Survey (MRS). The CVF comprised of two sections; the face validity statement (seven items) and the content validity statement (eight items). The MRS comprised of sic statements about the ability to follow the ABL module for each unit. Both instruments allows the sample to rate items on 4-point Likert scale (1= strongly disagree, 2 =disagree, $3=$ agree, $4=$ strongly agree). These instruments were validated by two mathematics education experts. The result of the pilot test revealed that the MRS has high reliability indices of 0.750 . This indicated that both instruments are appropriate to be used in this study.

Data Analysis

In this study, to achieve the first objective, the Content Validity Index (CVI) was calculated as an empirical measurement analysis to validate the validity of the module (Lynn, 1986). Upon completion of validity measure, the reliability of the ABL module was established to achieve the second objective if the study. Cronbach's Alpha coefficient is widely used to measure the reliability of Likert data that forms the psychometric instrument (Creswell, 2018; Ramasamy, Rahman, Manaf, \& Said, 2018). The value of Cronbach's Alpha coefficient varies from 0.00 to 1.00 and the alpha value of .65 to 95 is satisfactory, showing that the module has appropriate levels of reliability.

\section{Results and Discussion}

The results and the discussion will be presented according to the research question of the study. (1) Does the developed ABL module for the Statistical Inference course have satisfactory validity? 


\section{INTERNATIONAL JOURNAL OF ACADEMIC RESEARCH IN PROGRESSIVE EDUCATION AND}

DEVELOPMENT

Vol. 8, No. 4, 2019, E-ISSN: 2226-6348 @ 2019 HRMARS

As mentioned above, the face and content validity of the ABL module are analyzed using the CVI. The CVI values for all three experts were presented in Table 1 (face validity) and Table 2 (content validity). Number 1 indicated a favorable rating (experts' rated as 3 or 4), whereas 0 means unfavorable rating (experts' rated as 1 or 2). In addition, the experts were also requested to give comments and additional suggestion to improve the ABL module. Using the CVI method, the acceptable standard for index of average congruity recommended by Lynn (1986)] is 0.10 for 2 to 4 evaluators. In this case, both indices of CVI for face validity and content validity is 1.00 . Therefore, the developed $A B L$ module could be considered as having good face and content validity, indicating that the $A B L$ module for the Statistical Inference course have satisfactory validity.

Table 1

CVI for Face Validity

\begin{tabular}{|c|c|c|c|c|c|c|c|c|}
\hline Item & Criteria & $\begin{array}{l}\text { Likert } \\
\text { scale }\end{array}$ & $\begin{array}{l}\text { Favourabl } \\
\text { e Rating }\end{array}$ & $\begin{array}{l}\text { Likert } \\
\text { scale }\end{array}$ & $\begin{array}{l}\text { Favourabl } \\
\text { e Rating }\end{array}$ & $\begin{array}{l}\text { Likert } \\
\text { scale }\end{array}$ & $\begin{array}{c}\text { Favoura } \\
\text { ble } \\
\text { Rating }\end{array}$ & CVI \\
\hline & & \multicolumn{2}{|c|}{ Expert 1} & \multicolumn{2}{|c|}{ Expert 2} & \multicolumn{2}{|c|}{ Expert 3} & \\
\hline 1 & $\begin{array}{l}\text { The format is } \\
\text { acceptable. }\end{array}$ & 4 & 1 & 3 & 1 & 4 & 1 & 1 \\
\hline 2 & $\begin{array}{l}\text { The instructions } \\
\text { are clear. }\end{array}$ & 4 & 1 & 4 & 1 & 4 & 1 & 1 \\
\hline 3 & $\begin{array}{l}\text { The Words used } \\
\text { are appropriate. }\end{array}$ & 4 & 1 & 4 & 1 & 3 & 1 & 1 \\
\hline 4 & $\begin{array}{l}\text { The font size is } \\
\text { appropriate. }\end{array}$ & 4 & 1 & 3 & 1 & 3 & 1 & 1 \\
\hline 5 & $\begin{array}{l}\text { The words } \\
\text { spelling are } \\
\text { correct. }\end{array}$ & 3 & 1 & 3 & 1 & 3 & 1 & 1 \\
\hline 6 & $\begin{array}{l}\text { The grammar } \\
\text { used is correct. }\end{array}$ & 3 & 1 & 3 & 1 & 3 & 1 & 1 \\
\hline \multirow[t]{2}{*}{7} & $\begin{array}{l}\text { The terms used } \\
\text { are appropriate. }\end{array}$ & 3 & 1 & 3 & 1 & 3 & 1 & 1 \\
\hline & & & & & & & $\mathrm{CVI}$ & 1.00 \\
\hline
\end{tabular}


Table 2

CVI for Content Validity

\begin{tabular}{|c|c|c|c|c|c|c|c|c|}
\hline $\begin{array}{l}\text { Ite } \\
\mathrm{m}\end{array}$ & Criteria & $\begin{array}{l}\text { Likert } \\
\text { Scale }\end{array}$ & $\begin{array}{c}\text { Favourabl } \\
\text { e Rating }\end{array}$ & $\begin{array}{l}\text { Likert } \\
\text { Scale }\end{array}$ & $\begin{array}{c}\text { Favourabl } \\
\text { e Rating }\end{array}$ & $\begin{array}{l}\text { Likert } \\
\text { Scale }\end{array}$ & $\begin{array}{c}\text { Favourabl } \\
\text { e Rating }\end{array}$ & CVI \\
\hline & & \multicolumn{2}{|c|}{ Expert 1} & \multicolumn{2}{|r|}{ Expert 2} & \multicolumn{2}{|c|}{ Expert 3} & \\
\hline 1 & $\begin{array}{l}\text { Related to the } \\
\text { learning outcomes }\end{array}$ & 4 & 1 & 4 & 1 & 4 & 1 & 1 \\
\hline 2 & $\begin{array}{l}\text { Can achieve the } \\
\text { learning standard. }\end{array}$ & 4 & 1 & 4 & 1 & 4 & 1 & 1 \\
\hline 3 & $\begin{array}{l}\text { Suitable with the } \\
\text { ability of the } \\
\text { Diploma Level } \\
\text { Students }\end{array}$ & 4 & 1 & 4 & 1 & 3 & 1 & 1 \\
\hline 4 & $\begin{array}{l}\text { Appropriate for } \\
\text { Diploma Level } \\
\text { students' } \\
\text { experience }\end{array}$ & 4 & 1 & 4 & 1 & 3 & 1 & 1 \\
\hline 5 & $\begin{array}{l}\text { Appropriate with } \\
\text { the adventure- } \\
\text { based learning } \\
\text { activities }\end{array}$ & 4 & 1 & 4 & 1 & 4 & 1 & 1 \\
\hline 6 & $\begin{array}{l}\text { Can improve } \\
\text { students' } \\
\text { achievement }\end{array}$ & 3 & 1 & 4 & 1 & 4 & 1 & 1 \\
\hline 7 & $\begin{array}{l}\text { Appropriate to the } \\
\text { time allocated }\end{array}$ & 3 & 1 & 4 & 1 & 4 & 1 & 1 \\
\hline & & & $C V$ & & & & & 1.00 \\
\hline
\end{tabular}

(2) Does the developed ABL module for the Statistical Inference course have satisfactory reliability?

To answer the research question 2 of the study, a survey was conducted to establish the reliability of the ABL Module (Sidek \& Jamaludin, 2005; Gitau, Kiragu, Kamau, 2018). The alpha Cronbach's value will indicate the degree of consistency among the users of the module in terms how they think or feel that they can achieve the learning objectives and can follow the activities in the module. The result of the internal consistency tests for the survey was reported to be 0.84 . Hence, the developed ABL module for the Statistical Inference Course has satisfactory reliability. (3) What are the two activities of adventure learning in the developed module?

The two activities in the developed module are as follows:

1) Adventure Based On Fox Flying Activity

a) Students are required to measure their pulse and blood pressure before performing Flying Fox Adventure activities and recording data in the Activity Form provided. 
Vol. 8, No. 4, 2019, E-ISSN: 2226-6348 @ 2019 HRMARS

b) Students do the Flying Fox Adventure activities.

c) Students take time while doing the Flying Fox Adventure activity using stop watch.

d) The student re-measures the pulse and blood pressure after the activity.

e) Students perform statistical analysis (min) of data obtained.

f) Students need to solve the following questions:

i. Determine the mean of student heart rate before and after the Flying Fox Adventure activity.

ii. Determine the mean of student blood pressure before and after the Flying Fox Adventure activity

iii. Interpret the data obtained in questions (a) and (b)..

2) Adventure Based On Abseiling Activities

a) Students are required to measure their blood and pulse, height and weight before abseiling.

b) Students perform abseiling activities.

c) Students measures the time taken to complete the abseiling activity using a stopwatch

d) Students re-measure blood pressure or pulse pressure after activity.

e) Students perform a statistical analysis (Correlation) of the data obtained.

f) Students need to complete is as follows:

i. The relationship between student heart rate before and after abseiling activities.

ii. The relationship between student blood pressure before and after abseiling activities

iii. The relationship between height and time of student abseiling.

iv. The relationship between weight and student time of abseiling.

The above results have shown that the $A B L$ method can be done by designing and researching projects that are smaller in size and scope, explore other content areas such as in the field of mathematics, and in this case the basic statistics course, as well as focus on higher education. Previous studies have indicated that adventure learning has only been implemented as a distance education approach in the K-12 environment in the context of large-scale projects focusing on socio-scientific issues of global concern (Veletsianos \& Kleanthous, 2009; Colombos, 2018). Thus, the opportunities, limits, and viability of adventure learning in other contexts have been investigated. In addition, through the processes of establishing the reliability of the ABL Module, we have found that the users of the module can achieve the learning objectives and follow the activities in the module.

The activities that have been designed in the module were based on the experiential learning theory, inquiry learning and outdoor learning. Those activities have adventure as a central theme and authentic as the activities were related to real life situation. Students were always be in two relationships; interpersonal and intrapersonal. They were also actively having a debrief session continuously. The debrief process is where the group reflects on what (what?) Happened during the activity, what it meant to the group members (so what?), and what each group member can take from the experience that will impact their lives beyond participation in the activity (now 
what?). This debrief session is an integral and essential aspect of abl (Stuhr, 2016). The enjoyment and engagement of the target users were also considered when designing the activities. These key principles of $A B L$ which mirrored the FRC are vitally important for students to equip them with future skills that enable them to succeed in today's world and prepare to be relevant in the future workforce.

A deeper understanding of the method and its implications on students' cognitive, affective and psychomotor domains is imperative in furthering adventure learning practice and experiences, and this study takes an initial step in that direction.

\section{Conclusion}

This study has successfully developed the ABL Module for Higher Learning Institutions with good validity and reliability that can serve as a guide for lecturers and can be extended to other courses. It is very pertinent to understand the aspects of the teaching and learning approach of $A B L$ as an alternative way of generating human capital. This study contributes to the area of teaching and learning of mathematics at the Higher Learning Institutions that mathematical learning must be systematically planned and adventure-driven to ensure that students acquire knowledge and values that will keep them prepared for the future. This is in line with the Malaysian National Higher Education Strategic Plan where one of the core aims is to improve the quality of teaching and learning. As an education University, Sultan Idris Education University (UPSI) is a teacher training center that trains prospective teachers and in-service teachers. As such, UPSI can serve as a reference center and provide ideas to lecturers, teachers and other educators in providing guidance on this method. This module can be commercialized at all levels of education from primary to higher education. Lecturers can also recommend to prospective teachers or teachers using approaches that foster 21st century skills. In addition, schools are able to produce human capital that has the mind and skills in line with the demands of the job market. This is because the development of human capital needs to be trained from the beginning of schooling.

\section{Acknowledgements}

We extend our gratitude to Universiti Pendidikan Sultan Idris (UPSI), Malaysia for providing the funds under the University Research Grant (Teaching and Learning) [Code No. 2018-0178-10701] that enabled us to conduct the research. Special thanks to the Diploma students as well as the third year undergraduate mathematics students form Mathematics Programme UPSI for their involvement in this research.

\section{Corresponding Author}

Associate Prof. Dr Nor'ain Mohd Tajudin

Mathematics Department, Faculty of Science and Mathematics, Sultan Idris Education University, 35900 Tanjong Malim, Perak, MALAYSIA

Email: norain@fsmt.upsi.edu.my 
INTERNATIONAL JOURNAL OF ACADEMIC RESEARCH IN PROGRESSIVE EDUCATION AND DEVELOPMENT

Vol. 8, No. 4, 2019, E-ISSN: 2226-6348 @ 2019 HRMARS

\section{References}

Aliu, J., \& Aigbavboa, C. (2019). Upscaling Construction Education: The Role of Construction Site Experiential Learning, In book: Advances in Human Factors in Training, Education, and Learning Sciences DOI: 10.1007/978-3-319-93882-0_45

Anderson-Butcher, D., Riley, A., Amorose, A., lachini, A., \&Wade-Mdivanian, R. (2014). Maximizing Youth Experiences in Community Sport Settings: The Design and Impact of the LiFE Sports Camp. Journal of Sport Management, 28(2), 236-249.

Beard, C. and Wilson, J. (2013). (3nd Ed.). Experiential Learning: A Handbook for Education, Training and Coaching. London: Kogan Page.

Beightol, J., Jevertson, J., Carter, S., Gray, S., \& Gass, M. (2012). Adventure Education and Resilience Enhancement. Journal of Experiential Education, 35(2), 307-325. https://doi.org/10.1177/105382591203500203

Binkley, M., Erstad, O., Herman, J., Raizen, S., Ripley, M., Miller-Ricci, M., Rumble, M. (2012). Defining Twenty-First Century Skills. In B. McGaw \& E. Care (Eds), Assessment and Teaching of 21st Century Skills (pp 17-.66). New York, NY: Springer.

Bowdridge, M. (2010). Outdoor adventure education in schools: Curriculum or pedagogy? Considerations for teacher preparation and program implementation. (Unpublished doctoral dissertation). Faculty of Education, Simon Fraser University.

Brown, G., Cooper-Thomas, H., Curtin, J., \& Dunham, A. H. (2019). Teaching for transformation: The 4E's of teaching future-ready graduates. Higher Education Research and Development Society of Australasia Annual Conference. Next Generation, Higher Education: challenges, Changes and Opportunities, at Auckland, July 2019.

Buettner, D. (1997). Africatrek: A Journey by Bicycle through Africa. Minneapolis: Lerner Publishing Group.

Buettner, D., \& Mason, D. (1996). Maya quest: Interactive expedition. Onion Press

Chapman, O. (2011). Elementary school teachers' growth in inquiry-based teaching of mathematics. ZDM Mathematics Education, 43, 951-963.

Chew, P. K. H., \& Dillon, D. B. (2014). Statistics anxiety update: Refining the construct and recommendations for a new research agenda. Perspectives on Psychological Science, 9 (2), 196-208. doi:10.1177/1745691613518077

Cooley, S. J., Holland, M. J. G., Cumming, J., Novakovic, E. G., \& Burns, V. E. (2014). Introducing the use of a semi-structured video diary room to investigate students' learning experiences during an outdoor adventure education groupwork skills course. Higher Education, 67(1), 105-121. http://doi.org/10.1007/s10734-013-9645-5

Colombos, A. (2018). Teaching a Second or a Foreign Language to Middle School Students with ADHD: Modern Greek Taught as in the USA as an Example. Multilingual Academic Journal of Education and Social Sciences, 6(1), 41-51.

Creswell, J. (2018). Educational Research: Planning, Conducting, and Evaluating Quantitative and Qualitative Research (6th Ed.). Upper Saddle River: Pearson.

Dickson, T., Gray, T., \& Mann, K. (2008). Australian Outdoor Adventure Activity Benefits Catalogue.

http://outdoorcouncil.asn.au/doc/OutdoorActivityBenefitsCatalogueFinal270808. 
INTERNATIONAL JOURNAL OF ACADEMIC RESEARCH IN PROGRESSIVE EDUCATION AND DEVELOPMENT

Vol. 8, No. 4, 2019, E-ISSN: 2226-6348 @ 2019 HRMARS

Doering, A., Scharber, C., Riedel, E., \& Miller, C. (2010). "Timber for president": Adventure learning and motivation. Journal of Interactive Learning Research, 21, 483-513.

Doering, A. (2007). Adventure Learning: Situating Learning in an Authentic Context. Innovate, 3(6). Retrieved from http://publication/uuid/5D308F59-23E1-458A-BB93-

Ford, P. (1986) Outdoor Education:Definition and Philosophy.Las Cruses, NM: ERIC Clearinghouse on Rural Education and Small Schools.

Fox, P., \& Avramidis, E. (2003). An Evaluation of an Outdoor Education Programme for Students with Emotional and Behavioural Difficulties. Emotional and Behavioural Difficulties. 8(4), 267-283.

Gal, I., \& Ograjensek, I. (2017). Official Statistics and Statistics Education: Bridging the Gap. Journal of Official Statistics, 33(1), $79-100$. https://www.researchgate.net/publication/313948078_Official_Statistics_and_Statistics _Education_Bridging_the_Gap

Gitau, G.G., Kiragu, D.N., Kamau, R. (2018). Effect of Heuristic Factors and Real Estate Investment in Embu County, Kenya, International Journal of Academic Research in Accounting, Finance and Management Sciences 8 (4): 30-38.

Hattie, J., Marsh, H., Neill, J., \& Richards, G. (1997). Adventure education and Outward Bound: Out-of-class experiences that make a lasting difference. Review of Educational Research, 67(1), 43-87.

Hui, S. K. F., \& Cheung, H. Y. (2004). How does learning happen for people participating in adventure training? Asia Pacific Education Review, 5(1), 76-87. http://doi.org/10.1007/BF03026281

Human, L. (2012). Adventure-based experiences during professional training in psychology : a follow -up study. South African Journal of Psychology, 42(4), 586 -597.

Johnson, R. R. \& Kuby, P. J. (2012). Elementary Statistics. Boston, MA: Cengage Learning.

Kalaian, S. A., \& Kasim, R. M. (2014). A Meta-analytic review of studies of the effectiveness of small-group learning methods on statistics achievement. Journal of Statistics Education, 22(1). doi:10.1080/10691898.2014.11889691

Karppinen, S. J. A. (2012). Outdoor Adventure Education in a Formal Education Curriculum in Finland: Action Research Application. Journal of Adventure Education and Outdoor Learning, 12(10, 41-62.

Kementerian Pendidikan Malaysia (2013).Pelan Pembangunan Pendidikan Malaysia 2013-2025. Kementerian Pendidikan Malaysia: Putrajaya.

Kementerian Pendidikan Malaysia (2015).Pelan Pembangunan Pendidikan Malaysia (PT) 20152025. Kementerian Pendidikan Malaysia: Putrajaya.

Kemp, J. E., Morrison, G. R., \& Ross, S. M. (2012). Designing Effective Instruction. Upper Saddle River, New Jersey: Prentice-Hall Inc.

Kolb, D. (1984). Experiential learning: Experience as the source of learning and development. Englewood Cliffs, NJ: Prentice Hall.

Kolb, D. A., \& Fry, R. (1975) Toward an Applied Theory of Experiential Learning. In: Cooper, C., Ed., Theories of Group Process, John Wiley, London, 33-57. 
INTERNATIONAL JOURNAL OF ACADEMIC RESEARCH IN PROGRESSIVE EDUCATION AND DEVELOPMENT

Vol. 8, No. 4, 2019, E-ISSN: 2226-6348 @ 2019 HRMARS

Larson, D. A. (2010). Adventure Learning : Not Everyone Gets to Play. In Honeyman, J. Coben, \& G. De Palo (Eds.), Venturing Beyond the Classroom: Volume 2 in the Rethinking Negotiation Teaching Series (pp. 201-216). Saint Paul: DRI Press.

Lynn, M. (1986). Determination and Quantification of Content Validity Index. Nursing Research, 35, 382-386.

Marlina, A., \& Shaharom, N. (2010). Hubungan Antara Kemahiran Berfikir Kritis Dengan Pencapaian Akademik Dalam Kalangan Pelajar Fakulti Pendidikan Universiti Teknologi Malaysia. Jurnal Teknologi (Sains Sosial), 52, 45-55.

McKenzie, M. D. (2000). How are adventure education program outcomes achieved? A review of the literature. Australian Journal of Outdoor Education, 5, 19-28.

McRae, N., Church, D., Woodside, J. M., Drewery, D., Anne, F., \& Pretti, T. (2019). Toward a Future-Ready Talent Framework for Co-operative and Work-Integrated Learning. Fifth International Conference on Higher Education Advances Conference, June 2019, DOI 10.4995/HEAD19.2019.9319

Miller, C., Veletsianos, G., \& Doering, A. (2008). Curriculum at forty below: a phenomenological inquiry of an educator/explorer's experience with adventure learning in the Arctic. Distance Education, 29(3), 253-267. http://doi.org/10.1080/01587910802395789

Miller, B. G., Hougham, R. J., \& Eitel, K. B. (2013). The practical enactment of Adventure Learning: Where will you All? TechTrends, 57(4), 28-33. http://doi.org/10.1007/s11528013-0674-9

Afifi, M. B. S. (2017). Pembangunan dan pengujian pengajaran berasaskan adventure terhadap pencapaian, pemikiran kritis dan kepimpinan bagi topik Statistik. Tesis Doktor Falsafah. Universiti Pendidikan Sultan Idris, Tanjong Malim, Perak.

Taib, M. H. \& Norlena, S. (2008). Modul Program Pendidikan Sukan dan Rekreasi UKM: Satu kesinambungan. Dicapai pada 21 April 2018. http://myais.fsktm.um.edu.my

Nor'ain, M. T. (2015). Exploring Mathematics Lecturer's Teaching and Learning Practices at Higher Learning Institution. International Journal of Contemporary Applied Science, 2(8), 81-90.

Nor'ain, M. T. \& Chinnappan, M. (2016). The Link between Higher Order Thinking Skills, Representation and Concepts in Enhancing TIMSS Tasks. International Journal of Instruction, 9(2), 199-214.

Noraini, I. (2005). Pedagogy in Mathematics Education. Second Edition Kuala Lumpur: Utusan Publication.

Panaoura, A. (2017). Inquiry-based teaching approach in mathematics by using the history of mathematics: A case study. CERME 10, Feb 2017, Dublin, Ireland.

Piskurich, G. M. (2016). Rapid Instructional Design: Learning ID Fast and Right, NJ, USA: John Wiley \& Sons, Hoboken.

Ramasamy, S. a/p, Rahman, F. A., Manaf, U. K. A., \& Said, R. R. (2018). The Inculcation of Higher Order Thinking Skills in History Subject through the Application of Multiple Intelligence Theory. International Journal of Academic Research in Progressive Education and Development, 7(4), 51-59.

Rhodes, H. M., \& Martin, A. J. (2013). Behavior Change After Adventure Education Courses: Do Work Colleagues Notice? Journal of Experiential Education, 37(3), 265-284. 
INTERNATIONAL JOURNAL OF ACADEMIC RESEARCH IN PROGRESSIVE EDUCATION AND DEVELOPMENT

Vol. 8, No. 4, 2019, E-ISSN: 2226-6348 @ 2019 HRMARS

Richey, R. C., \& Klein, J. (2007). Design and Development Research Methods, Strategies, and Issues. Mahwah, NJ: Lawrence Erlbaum Associates.

Riggins, R. D. (1986) Effective Learning in Adventure-Based Education: Setting Directions for Future Research, The Journal of Environmental Education, 18:1, 1-6, DOI: 10.1080/00958964.1986.9942722

Schutz, C. (2008). Education through exploration: A new theory in teaching and learning science. http://www.jason.org/uploads/PublicUploads/CuteSoft/Highlights/whitepaper08/educa tion_through_exploration.pdf.

Sibthorp, J., \& Jostad, J. (2014). The social system in outdoor adventure educa-tion programs. Journal of Experiential Education, 37(1), 60-74.

Sidek, M. N., \& Jamaludin, A. (2005). Pembinaan Modul: Bagaimana Membina Modul Latihan dan Modul Akademik. Serdang: Penerbit Universiti Putra Malaysia

Hamisah, S. T., \& Marlia, P. (2018). Framing Malaysian Higher Education 4.0: Future-Proof Talents, Kuala Lumpur: Ministry of Higher Education Malaysia.

Stuhr, P. T., Sutherland, S., Ressler, J., \& Ortiz-Stuhr, E. M. (2016). The ABC's of Adventure Based Learning. Strategies, 29(1), 3-9. http://doi.org/10.1080/08924562.2015.1111787

Yeoh, C. L., Afifi, M. B. S., Ket, L. L., \& Narmal, S. (2015). Aplikasi Matematik. Bangi: Pelangi Professional Publishing Sdn. Bhd. 